\title{
Kırıkkale'de Suç Perspektifi ve Tedbirler
}

\author{
Rafet ÇEVIKBAŞ ${ }^{1} \quad$ Ufuk COŞTAN ${ }^{2}$ \\ ${ }^{1}$ Kırıkkale Üniversitesi, İktisadi ve İdari Bilimler Fakültesi, Siyaset Bilimi ve Kamu Yönetimi Bölümü, Kırıkkale \\ ${ }^{2}$ Kırıkkale Üniversitesi, Sosyal Bilimler Enstitüsü, Siyaset Bilimi ve Kamu Yönetimi Bölümü, Kırıkkale
}

\begin{abstract}
Özet
Bu çalışmanın amacı Kırıkkale ilinde suç perspektifini ortaya koymak ve bunun ışığında çözüm önerileri geliştirmektir. Suç perspektifi ortaya koyulurken Kırıkkale Adliyesi'nin 2010- 2013 yılı verileri esas alınmıştır. Ancak asayiş olayları sonucu açılan ceza davaları çalışmaya konu edilebilmiştir. Suç perspektifi ortaya konduktan sonra güvenlik tedbirlerinin yanında alınabilecek önleyici özellikte olan psikolojik, sosyolojik, ekonomik, siyasi, hukuksal, v.b. tedbirler ortaya konmaya çalışılmıştır.

Anahtar Kelimeler: Suç Perspektifi, Suç, Suç Önleme.
\end{abstract}

\section{The Criminal Perspective and the Measures in Kırıkkale}

\begin{abstract}
The aims of this study are to expose the criminal perspective in Kirikkale, and in the lights of this, to present solutions. The study bases on datas belong to the years between 2010- 2013, are taken from Courthouse of Kirikkale. However, in the study only criminal cases about crimes against public order were examined. After exposing criminal perspective, the study tries to present psychological, socialogical, economical, political, judicial, etc. measures in order to prevent crimes.
\end{abstract}

Keywords: Criminal Perspective, Crime, Crime Prevention.

\section{Giriş}

Türkiye İstatistik Kurumunun adrese dayalı nüfus kayıt sisteminin verilerine göre; Kırıkkale il nüfusu 274.727 olup, il merkezi nüfusu ise 192.473 'tür. Nüfusun 95.605 'i erkek, 96.868'i kadındır (TÜİK, 2013). Çalışmanın kapsamı Kırıkkale il merkezi ile sınırlı olup, ilçeleri kapsamamaktadır. Çalışmaya temel teşkil eden veriler Kırıkkale Adliyesi’nden alınmış olup, kapsamı 2010-2013 yılları ile sınırlandırılmıştır. $\mathrm{Bu}$ sınırlandırma Adalet Bakanlığı'nın UYAP sistemine geçmesi ile birlikte geçmişe ait verilerin henüz sisteme aktarılamamış olmasından kaynaklanmaktadır. Çünkü UYAP Bilişim Sistemi 2000 yılında iki aşamalı olarak başlatılmış bir proje olup, 2001 yılında Adalet Bakanlığı Merkez Birimleri'nin otomasyonunu sağlayan UYAP I projesi tamamlanmış; 2005 yılında ise taşra teşkilatının otomasyonunu kapsayan UYAP II tamamlanarak faaliyete geçirilmiştir (UYAP, 2013). Bununla birlikte; ancak 2010 yılı itibariyle sistem tüm Türkiye çapında etkin olarak kullanılmaya başlanılmıştır.

Yapılan çalışmaya esas olan veriler Kırıkkale Adliyesi'nde açılan ceza davaları ile sınırlıdır. Soruşturması devam eden veya soruşturma safhasında kovuşturulmasına gerek görülmeyen olaylar çalışma dişında tutulmuştur.

Genel anlamda suç; sosyal, psikolojik, ekonomik ve hukuki alanları da ilgilendiren toplum kurallarının yazılı hale gelmiş şekli olan kanunlara uymayan davranışlara verilen addır. Suç, kamu güvenliğini tehdit eder nitelikte ve bireyler üzerinde can veya mal kaygısı yaratır niteliktedir. Son yıllarda tüm Türkiye'de suç oranının arttığı görülmektedir.

Artan suç oranına paralel olarak güvenlik güçlerinin personel ve araç-gereç sayısında da artış olmuştur. Kırıkkale ili Orta Anadolu bölgesinin tipik özelliklerini taşıyan bir ildir. $\mathrm{Bu}$ açıdan bir örnek teşkil edeceği düşüncesi ile Kırıkkale ilinde suç perspektifi ve alınabilecek tedbirler üzerine bir çalışmanın istatistikî verilere dayanılarak yapılması düşünülmüştür. Bu çalışmanın ilgi alanı Kırıkkale ilini örnek alarak, asayiş olayları açısından bir değerlendirme yapmak ve güvenlik tedbirlerinin yanında alınabilecek, suçun işlenmesini engellemeye yönelik tedbirleri ortaya koymak olacaktır.

\section{Suç ve Suçlu Kavram ve Kapsamı}

Hukuki açıdan suç, kanun koyucu tarafından daha önceden belirlenmiş ve ceza öngörülmüş fiildir. Suç, topluma veya özelde bireylere zarar veren ya da tehlikeli olan eylem, tavır, davranış ve harekettir (Araştırma ve Etütler Merkezi, 2003: 4). Suç oluşturan her fiil bir ceza ile yaptırım görür. Söz konusu cezalar suç işlenmesini engellemek için caydırıcı etkiye sahip olmak zorundadır. Cezaların caydırıcı etkiye sahip olması için temelde 3 unsuru içermesi gerekmektedir: Kesinlik, hızlılık ve şiddetlilik (Dolu, 2009 a: 4).

Kesinlik ilkesi her suçun cezasının önceden ayrıntılı bir şekilde tarif edilmesi ve işlenen suç karşılığında yaptırımın kesin bir şekilde belli olmasını ifade etmektedir. Hızlılık ilkesi ile suçun karşılığında çekilecek cezanın zaman kaybedilmeden çektirilmesi ifade edilmiştir. $\mathrm{Bu}$ ilke uygulandığında suç işlemeye meyilli diğer kimseler için caydırıcı olacaktır. Şiddetlilik ilkesi ise işlenen her suça ayrı ayrı belirlenmiş ceza tür ve sürelerini ifade etmekte ve cezanın şiddeti suçun tekrar işlenmesini caydırıcı nitelikte olmalidır. 
$\mathrm{Bu}$ üç unsurun birlikte tavizsiz uygulanması ve ceza çekme safhasında uygulanacak ıslah politikaları suç işlendikten sonra suçluları tekrar topluma kazandırma ve suç işlenmesini önleme konusunda başarının anahtarıdır.

Asıl önemli olan suç işlendikten sonra çözümler üretmek değil, suç işlenmeden suçu önleyebilmektir. Çalışmanın esas konusu olan bu noktada ilk olarak rutin aktiviteler teorisine göre suç mekanizmasını kısaca özetlemek faydalı olacaktır. Rutin aktiviteler teorisinde diğer teorik yaklaşımların tersine suçlunun özellikleri yerine oluşan suç eyleminin zamansal ve mekânsal bileşenleri analiz edilmiştir. Bir suçun işlenmesi için suç işlemeyi kafasına koymuş potansiyel bir suçlu, suçluyu kendisine çekecek kadar değerli bir hedef ve suça hedef olan nesne veya kimseyi koruyabilecek koruyucuların yokluğu veya eksikliği gereklidir. $\mathrm{Bu}$ doğrultuda suç oluşumu, şematik olarak aşağıdaki şekilde daha açık olarak izah edilebilmektedir (Dolu, 2012: 127).

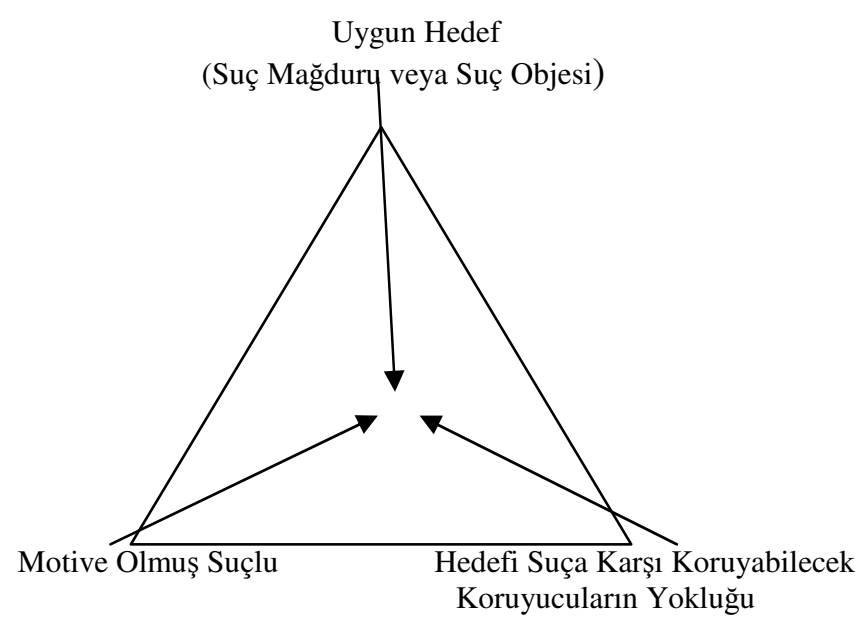

Şekil 1: Rutin Aktiviteler Teorisi’ne Göre Suç Mekanizması

Rutin aktiviteler teorisine göre suçun oluşması için gerekli üç unsurdan ilki motive olmuş suçlulardır. Bu yaklaşıma göre pek çok insan potansiyel suçlu olarak görülür ve suç işlemek için karşılarına uygun suç işleme fırsatının çıkmasını beklemektedirler. Başka bir deyişle çoğu kişinin içerisinde suç işleme potansiyeli bulunmaktadır ve uygun şartlar oluştuğunda bu potansiyel suça dönüşmektedir.

Teorinin ikinci unsuru koruyucuların yoksunluğudur. Suçun oluşması için mutlaka hedefin koruyucularının eksikliği gereklidir. Tam olarak korunan bir hedef suç işlenmesini büyük oranda önleyecektir. Rutin aktiviteler teorisine göre mekânsal olarak suç evde, işte ve diğer yerlerde meydana gelmektedir (Dolu, 2012: 129). Mekânın belli olduğu ev ve işyerinde gerekli tedbirler alındığında suçun işlenmesi zordur. Ancak diğer yerler başlığı altındaki mekânın belli olmadığı ortamlar suç oluşumu için idealdir.

Teorinin son ve merkezi noktası uygun hedeftir. Uygun hedeften kastedilen suça konu olabilecek kadar değerli eşya veya kimsedir. Hedefin kolay erişilebilir, dışarıdan görünebilir ve koruyucularının eksik oluşu suçun oluşmasına yol açmaktadır. Suça konu olan uygun hedef için kıstas değerli ve kolay elde edilebilir olmasıdır. Gecenin bir vakti kamera ve aydınlatması olmayan bir sokakta yürüyen bir kimse veya yolun kenarında camı açık vaziyette bırakılmış bir araba uygun birer hedeftir.
Suçun mağduru olmayı belirleyen beş temel unsur bulunmaktadır (Dolu, 2012: 131):

$\checkmark$ Hedefin görünür olması,

$\checkmark$ Hedefin değerli ve arzu edilebilir olması,

$\checkmark$ Hedefin suça karşı savunmasız olması,

$\checkmark$ Hedefin hareket kabiliyeti,

$\checkmark$ Hedefin müsait veya erişilebilir olması.

Sokak ortasında bir deste parayı çıkartıp saymak veya arabanın koltuğunda görünür vaziyette çanta bırakmak hedefin görünür olmasına, yan yana duran iki araçtan bir tanesinin pahalı ve yeni olması hedefin değerli olmasına, yaşlı bir kadın hedefin suça karşı savunmasız olmasına, çalınıp götürülmesi kolay olan arabalar hedefin hareket kabiliyetine ve ailesi tarafından başıboş bırakılmış bir genç hedefin müsait olmasına örnek gösterilebilir (Dolu, 2012: 131-133).

Bir suçun oluşabilmesi için yukarıda bahsi geçen motive olmuş suçlu, uygun hedef ve koruyucuların eksikliği aynı anda bulunmalıdır. Bu üç unsurdan herhangi birinin eksikliği suç işlenmesini engellemek için yeterlidir. Suça hedef olan nesne veya kimseyi koruyabilecek koruyucular bu çalışmanın konusunu içermektedir. Koruyucular dendiğinde polis ve jandarma gibi sadece güvenlik güçleri algılanmamalıdır. Tam tersine suç anında bir güvenlik gücünün olay yerinde olma ihtimali oldukça düşüktür. Bir köpek, bir sopa, bir arkadaş veya suç anında bizi o suçun mağduru olmaktan koruyabilecek herhangi bir şey koruyucudur. Örneklerden de anlaşılacağı üzere koruyucu illaki üzerinde üniforması, elinde silahı olan güvenlik gücü değildir (Dolu, 2009 b: 8).

Suçun önlenmesinde kolluk görevlilerinin yanında diğer kurumların ve toplumun alacağı tedbirler de önemlidir. Alınacak her türlü tedbirle suç oluşma riski azaltılabilmektedir. Aydınlatılan bir sokak, kilitlenen bir araba kapısı, kamera sistemi kurulan bir park, ıslah edilmiş tinerci gençler veya hırsızlığın çok olduğu bir bölgeye yerleştirilen bir uyarı levhası bile suç oluşması riskini azaltacaktır.

Suç oluşması için iki ayrı risk grubu bulunmaktadır. Birinci risk grubu mevcut olan riskler, ikinci risk grubu ise mevcut şartlardan dolayı ileride ortaya çıkabilecek aşağıda belirtilen risklerden oluşmaktadır (Geleri, 2010: 25):

\section{Birinci Risk Grubu:}

$\checkmark$ Yolun kenarında kontak anahtarı üzerinde bırakılmış olarak park edilen bir araç,

$\checkmark$ Aydinlatmasi olmayan bir sokak,

$\checkmark$ Üzerinde fazla miktarda nakit para taşıyan bir kişi,

$\checkmark$ Güvenlik tedbirleri almayan kuyumcu, döviz büroları ve bankalar,

$\checkmark$ Penceresi açık bırakılan bir ev,

$\checkmark$ Uyuşturucu kullanımı,

$\checkmark \quad$ Aşırı alkol kullanımı.

\section{İkinci Risk Grubu:}

$\checkmark \quad$ Çocuklar ve gençler için herhangi bir oyun alanı ve boş zamanları değerlendirme merkezi olmayan bir yerleşim alanı,

$\checkmark$ İşsizliğin yoğun olduğu bir yerleşim alanı,

$\checkmark$ Kimsesiz çocuklar,

$\checkmark$ Plansız ve bakımsız yerleşim alanları,

$\checkmark$ Dar ve trafik sorunu yoğun olan yollar ve yerler, 
$\checkmark$ Otopark sorunu olan yerleşim alanları.

Yukarıda sözü edilen; birinci grupta yer alan risklere karşı alınabilecek bireysel tedbirler yeterliyken, ikinci grupta yer alan riskler için hem kent yöneticileri hem de güvenlik güçleri ortak olarak çözüm geliştirebilmektedir. Suçun önlenmesinde kilit nokta suça karşı alınacak bireysel tedbirlere ilaveten değişen zamana ve mekâna göre yapılacak analizler sonucu kent yöneticileri, kolluk güçleri ve diğer kurum ve kuruluşlar arasında koordinasyon sağlanarak hedefleri suç işlenmesi için uygun olmaktan uzaklaştırmaktır.

\section{Kırıkkale İl Merkezi 2010-2013 Yılları Arasında İşlenen Suçlar Sonucu Açılan Ceza Davaları ve Çözüm Önerileri}

Kırıkkale ilinde yoğunluklu olarak kişilere karşı, mal varlığına karşı, topluma karşı, millete ve devlete karşı işlenen suçlarla birlikte kaçakçılık suçları meydana gelmektedir. Yukarıda bahsi geçen suç türleri istatistikî verilere dayanılarak ayrı ayrı açıklanıp, çözüm önerileri geliştirilmeye çalışılmıştır.

\subsection{Asayiş Olayları}

2010-2013 yılları arasında meydana gelen asayiş suçları kişilere, mal varlığına, topluma, millete ve devlete karşı işlenen ve kaçakçılık suçlarından oluşmaktadır. Bu dönemde toplam 417 olay hakkında dava açılmış olup, açılan davaların 144(\%34,53)'ünü kişilere karş1 suçlar, 115(\%27,57)'ini malvarlığına karşı suçlar, 28(\%6,71)'ini topluma karşı suçlar, $65(\% 15,58)$ 'ini millete ve devlete karşı suçlar, $65(\% 15,58)$ 'ini ise kaçakçılık suçları oluşturmaktadır.

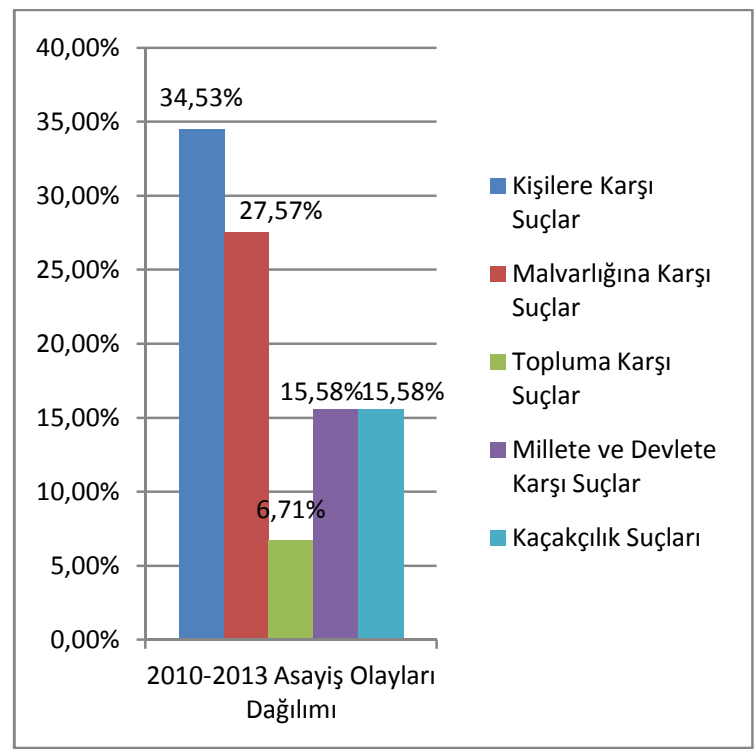

Grafik 1. 2010- 2013 Yılları Arasında Kişilere, Mal Varlığına, Topluma, Millete ve Devlete Karşı İşlenen ve Kaçakçılık Suçlarının Mukayesesi

Kaynak: Kırıkkale Adliyesi Arşivi (2013)

Grafik incelendiğinde Kırıkkale ilinde yoğunluklu olarak kişilere karşı suçların ve mal varlığına karşı suçların işlendiği görülmektedir. Kişiye karşı suçları öldürme, müessir fiil, hakaret-sövme, tahrik ve kişiye karşı şiddet kullanılması gibi suçlar oluşturmaktadır. Mal varlığına karşı suçları ise mala zarar verme, dolandırıcılık, emniyeti suiistimal, hırsızlık, yağma gibi suçlar oluşturmaktadır. Kırıkkale ilinde bu iki suç tipinin ağırlıklı olarak görülmesinin başlıca sebepleri: 1989 yılında il olan Kırıkkale'de şehir kültürünün tam olarak oluşmamış olması, vatandaş profilinin çevre illerden Makine Kimya fabrikalarında çalışmak için göç etmiş olan çok geniş bir yelpazeden oluşması ve özellikle hırsızlık olayları açısından konum olarak anayol güzergâhı üzerinde bulunması sebebiyle suç işleyip kaçmaya müsait olmasıdır. Kaçakçılık olayları açısından bir değerlendirme yapıldığında ise şehrin hem karayolu hem de demiryolu olarak doğu ile batı arasında geçiş güzergâhı üzerinde olması bu tarz suçların yoğun olarak görülmesine yol açmaktadır.

Kaçakçılık olayları içerisinde ağırlıklı olarak kaçak tütün ve tütün mamulleri ile akaryakıt kaçakçılığı göze çarpmaktadır. Yukarıda sözü edilen asayiş olaylarını; kişilere, mal varlığına, topluma, millete ve devlete karşı işlenen ve kaçakçılık suçları olarak ayrı ayrı gruplandırıp incelememiz daha isabetli bir yaklaşım olacaktır.

\subsubsection{Kişilere Karşı Suçlar ve Çözüm Önerileri}

2010-2013 yılları arasında kişilere karşı suçlardan dolayı toplam 144 dava açılmış olup, bu davaların 50(\%34,72)' sini hayata ve vücut dokunulmazlığına karşı suçlar, 48(\%33,33)'ini cinsel dokunulmazlığa karşı suçlar, 46(\%31,94)'sını ise hürriyete ve şerefe karşı suçlar oluşturmaktadır.

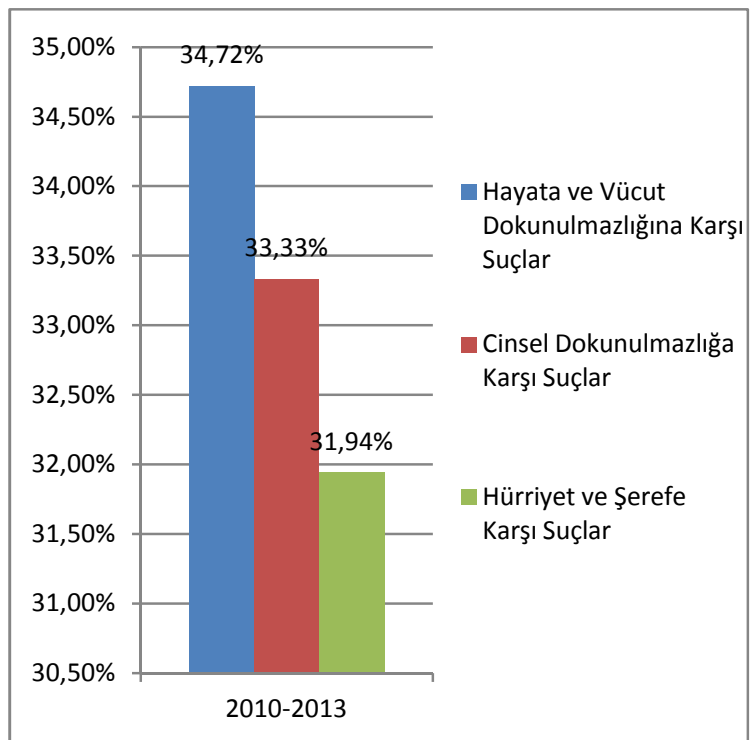

Grafik 2. 2010- 2013 Kişilere Karşı Suçların Mukayesesi Kaynak: Kırıkkale Adliyesi Arşivi (2013)

Kişilere karşı suçlar dendiğinde cinayet, yaralama, cinsel saldırı ve istismar, tehdit, şantaj, hakaret ve konut dokunulmazlığını ihlal gibi suçlar akla gelmektedir. 20102013 yılları arasındaki istatistiklere bakıldığında Kırıkkale ilinde sirasiyla $\% 34,72$ oranla hayata ve vücut dokunulmazlığına karşı suçlar, \%33,33 oranla cinsel dokunulmazlığa karşı suçlar ve \%31,94 oranla hürriyete ve şerefe karşı suçların meydana geldiği görülmektedir.

Hayata ve vücut dokunulmazlığına karşı suçlar dendiğinde ilk akla gelenler cinayet, yaralama, trafik kazası sonucu yaralama ve öldürme suçlarıdır. Cinayet ve yaralama suçları konusunda çalışmamız itibari ile proaktif ${ }^{1}$ yaklaşım çok mümkün değildir. Genel olarak eğitim seviyesi ve

\footnotetext{
${ }^{1}$ Olabilecek olayları önceden öngörerek pozisyon almak, yeni koșullar oluşturmak ya da mevcut koşulların seyrini değiştirmek için inisiyatif almak.
} 
toplum kültürü ile ilgilidir. Kırıkkale ili 1989 yılında sonradan il olmuş bir şehrimizdir. Kırıkkale 1989 sonrası çevre şehirlerden yoğun olarak göç almıştır. Bu sebeple şehir kültürü henüz çok yeni ve kozmopolit bir yapıdadır. Cinayet ve yaralama olaylarının sebepleri araştırıldığında karşımıza çok geniş bir yelpaze çıkmaktadır. Önlenebilir olması bakımından içki ve benzeri kötü alışkanlıklar sebebiyle meydana gelen olaylar incelenmiştir.

Kırıkkale ili şehir merkezinde çarşı içerisinde ve şehir dışında Samsun karayolu üzerinde çok sayıda bar, pavyon ve içkili restoran bulunmaktadır. Meydana gelen yaralama olaylarının büyük kısmı bu mekânlarda gece vakti meydana gelmekte ve olay faillerinin alkollü olduğu göze çarpmaktadır. Ayrıca şehir merkezinde bulunan içkili mekânların çarşı ile iç içe olmasından dolayı yarattığı tehlike apayrıdır. Alınabilecek tedbirler şöyledir:

$\checkmark$ İçkili mekânlar için şehir dışında ayrı bir bölge oluşturulup yaşam alanlarından soyutlanması ve bu bölge dışında bar, pavyon ve benzeri mekânların açılmasına izin verilmemesi,

$\checkmark$ Kolluk güçleri tarafından içkili mekânlar bölgesinin denetimlerinin eksiksiz yapılması,

$\checkmark$ Alkolün neden olduğu yaralamalı veya ölümlü kazaları engellemek için bahse konu bölgenin giriş ve çıkışlarında trafik denetimlerinin aralıksız yapılması,

$\checkmark$ Suça karışan kimselerin veya aranan şahısların bahse konu yerlere sıklıkla gittiği göz önüne alındığında kolluk tarafından yapılacak olan suç kaydı denetimlerinin aralıksız yapılması,

$\checkmark$ Mekân sahipleri tarafından hem içeriye hem dışarıya yerleştirilecek kameralar ile meydana gelebilecek olayların faillerinin tespitinin kolaylaştırılması,

$\checkmark$ Bahse konu mekânlar için işletme sahipleri tarafından tahsis edilecek özel güvenlik görevlileri sayesinde olayların önlenmesi sağlanmalıdır.

Kırıkkale ilinde cinayet ve yaralama olaylarına karışan suç failleri incelendiğinde toplum tarafından dışlanmış ve metruk yerlerde yaşayan kişiler karşımıza çıkmaktadır. 1980'li yıllarda Wilson ve Kelling tarafından geliştirilen kırık camlar teorisi bu olguyu en iyi şekilde açıklamaktadır. Kırık camlar teorisine göre kontrolsüzlük, denetimsizlik, sahipsizlik, bakımsızlık ve ilgisizlik hissi uyandıran yerler suç üretmektedir (Doğan, 2011: 31).

Kırıkkale il merkezinde ve yakın çevresinde çok sayıda metruk bina bulunmaktadır. $\mathrm{Bu}$ binaların kolluk güçleri tarafından sürekli kontrol edilmesi olanaksızdır. Bahse konu binalar tinerci ve balici gibi kimselerin yaşam alanı haline gelmiştir. Uyuşturucu kullanan kimseler veya suç eşyası saklamak isteyen kimseler bu binaları kullanmaktadır. Bu binaların bakımlarının yapılması ve kullanıma açılması pratikte çok mümkün görünmemektedir. Çözüm olarak bina girişlerinin kapatılması ve bu tarzda binaların giriş ve çıkışlarının aydınlatılması caydırıcı olabilecektir. Diğer taraftan toplum tarafından dişlanmış uyuşturucu bağımlısı, tinerci ve balici gibi kimselerin 1slahı suç önlenmesinde çok etkili olup devlet tarafından yapılması gereken zahmetli bir süreçtir.

Trafik kazaları sonucu yaralama veya öldürme olayları incelendiğinde Kırıkkale ilinin İç Anadolu için bir kavşak noktası olduğu ve trafik akışının çok yoğun olduğu görülmektedir. Özellikle yaz aylarında trafik akışı yurt dışından gelen vatandaşlarımızın ve tatil sezonu olmasının da etkisiyle çok yoğunlaşmaktadır. Trafik kazalarının yoğunlaştığı Samsun ve Kayseri karayollarının kritik noktalarına kurulacak sabit radar sistemleri ve seyyar radar uygulamaları aşırı hız sebebiyle oluşan trafik kazalarını azaltmaya yardımcı olacaktır.

Hürriyete ve şerefe karşı suçlar dendiğinde tehdit, hakaret ve şantaj gibi suçlar göze çarpmaktadır. Söz konusu suçlara proaktif yaklaşım cinayet ve yaralama olaylarına benzer şekilde yapılabilmekle birlikte, toplumun sosyal ve kültürel yapısıyla yakından ilişkilidir.

Kırıkkale ilinde kişilere karşı suçlar incelendiğinde \%33,33 oranla göze çarpan cinsel dokunulmazlığa karşı suçlar göze çarpmaktadır. Söz konusu suçlar sadece tecavüz şeklinde algılanmamalıdır. Sözlü saldırı, fiziksel taciz, dokunma, okşama, zorla öpme, sürtünme, evlilik içi zorla ilişki gibi değişik şekillerde görülmektedir. Türk Ceza Kanunu ile her fiil için ceza yaptırımları belirlenmiştir. Kırıkkale ili gibi muhafazakâr yapılı bir il görüntüsünü yansıtan bir yerde bu tarz suçların yoğunlukta olması ilgi çekicidir. Suç mağdurları arasında yetişkinlerin yanında çocuklar da bulunmaktadır. Çocukların mağdur olduğu olaylar genellikle park gibi oyun alanlarında yalnız olan çocukların kandırılmak suretiyle istismar edilmesi şeklinde gerçekleşmiştir. Suç failleri açısından yapılan analiz sonucunda 39 şüpheliden \%8'e denk gelen bir oran olan 3 şüphelinin kadın olduğu tespit edilmiştir. Kadınların şüpheli olduğu olaylar reşit olmayan erkekle cinsel münasebet kurmak şeklinde gerçekleşmiştir.

2010-2013 yılları arasında toplam 48 cinsel dokunulmazlığa karşı suç meydana gelmiştir. 2010- 2013 yılları arasında gerçekleşen 48 olayın 39(\%81)'unun failleri tespit edilmiş olup, 9(\%19)'u ise faili meçhul kalmıştır. 12 olayın mağduru çocuktur.

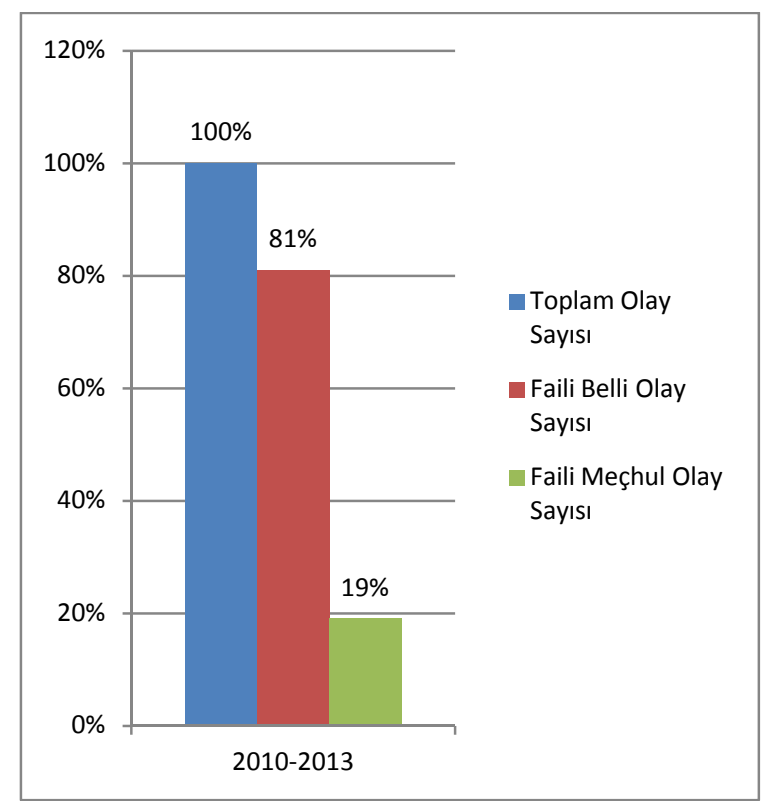

Grafik 3. 2010- 2013 Cinsel Dokunulmazlığa Karşı Suçların Faili Meçhul- Faili Belli Olay Mukayesesi

Kaynak: Kırıkkale Adliyesi Arşivi (2013)

Cinsel dokunulmazlığa karşı suçların içerisinde yer alan çocukların cinsel istismarı dikkat çekilmesi gereken bir konudur. Fiili hareket olmaksızın, dokunma, okşama, teşhir gibi yollarla da meydana gelebilmektedir. Cinsel istismara 
uğrayan çocuk çoğu zaman bunu bir oyun sanabilir ve ne ile karşı karşıya kaldığının farkında olmayabilir. Cinsel saldırıya maruz kalan çocuklarda hem çocukluk döneminde hem de ileriki yaşlarda ağır travmalar görülmektedir.

Çocukluk döneminde geceleri kâbus görme, sürekli kaygılılık hali, belli kimselerle yalnız kalmaktan korkma, asosyallik gibi travmalar görülmektedir. İlerleyen yaşlarda ise yine içe kapalılık, psikolojik problemler, asosyallik, cinsel soğukluk ve benzeri sorunlar ortaya çıkmaktadır. Cinsel istismara maruz kalan çocuklarla kolluk görevlileri kesinlikle birebir temastan kaçınmalıdır. Mutlaka bir psikolog vasıtası ile çocuk ile iletişim kurulmalıdır. Cinsel istismar sonrası ise ailenin ve çocuğun yaşanan travmayı atlatmak için psikolojik destek alması çok önemlidir.

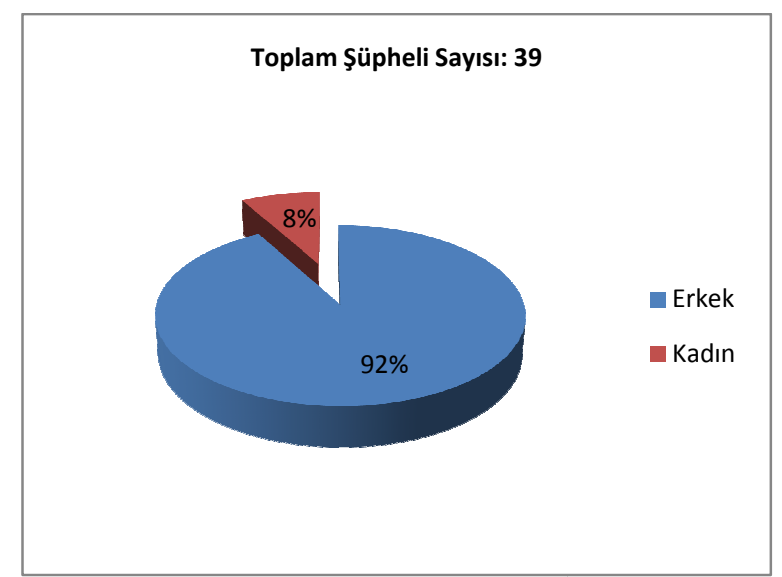

Grafik 4. 2010- 2013 Cinsel Dokunulmazlığa Karşı Suç Şüphelilerinin Cinsiyet Dağılımları

Kaynak: Kırıkkale Adliyesi Arşivi (2013)

Grafikte görüldüğü gibi yaygın inanışın aksine cinsel istismar şüphelilerinin bir bölümünü kadınlar oluşturmaktadır. Kadınların şüpheli oldukları olaylar genellikle reşit olmayan kimselerle cinsel ilişki kurmak şeklinde gerçekleşmiştir.

\subsubsection{Malvarlığına Karşı Suçlar ve Çözüm Önerileri}

2010-2013 yılları arasında malvarlığına karşı suçlardan dolayı toplam 115 dava açılmış olup, bu davaların 82(\%71,30)'sini hırsızlık, 33(\%28,70)'ünü ise diğer suçlar oluşturmaktadır.

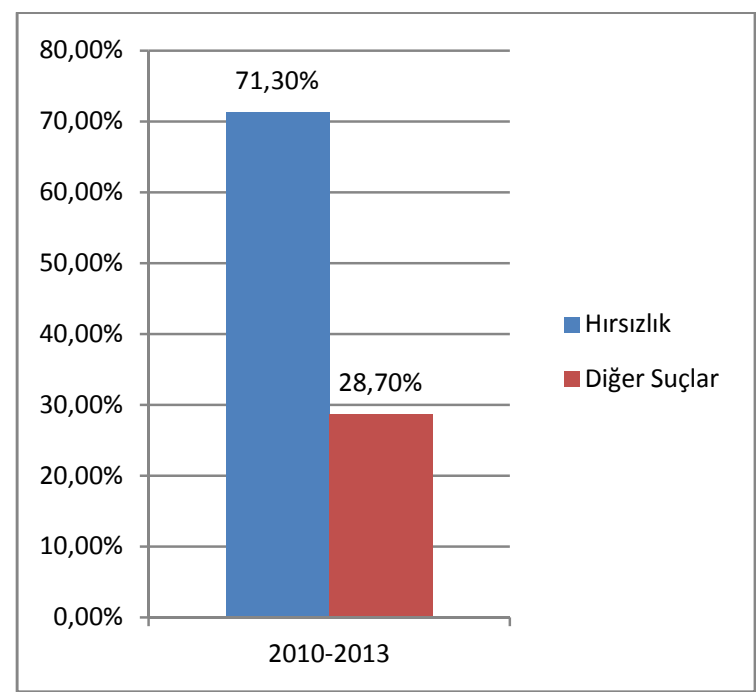

Grafik 5. 2010- 2013 Malvarlığına Karşı Suçların Mukayesesi
Kaynak: Kırıkkale Adliyesi Arşivi (2013)

Grafiği incelediğimizde malvarlığına karşı meydana gelen suçların büyük bölümünü hırsızlık suçlarının oluşturduğu görülmektedir. Geriye kalan \%28,70'lik bölümü ise başkasının malına zarar verme, dolandırıcılık, emniyeti suiistimal ve yağma gibi suçlar oluşturmaktadır.

2010-2013 yılları arasında toplam 82 hırsızlık olayı hakkında dava açılmış olup, meydana gelen olayların 51(\%62,20)'inin failleri belirlenmiş, 31(\%37,80)'inin ise failleri belirlenemeyip faili meçhul olarak kalmıştır.

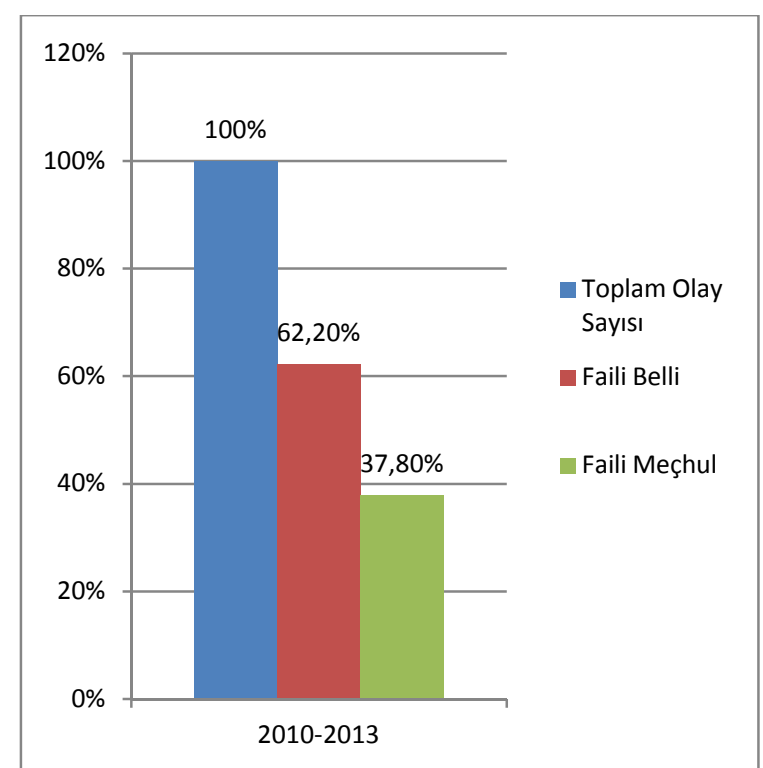

Grafik 6. 2010- 2013 Hırsızlık Suçlarının Mukayesesi Kaynak: Kırıkkale Adliyesi Arşivi (2013)

Hırsılık olaylarının oluş zamanlarına göre dağılımları analiz edildiğinde genel olarak Mart, Nisan ve Temmuz aylarında ağırlıklı olarak meydana geldiği görülmektedir.

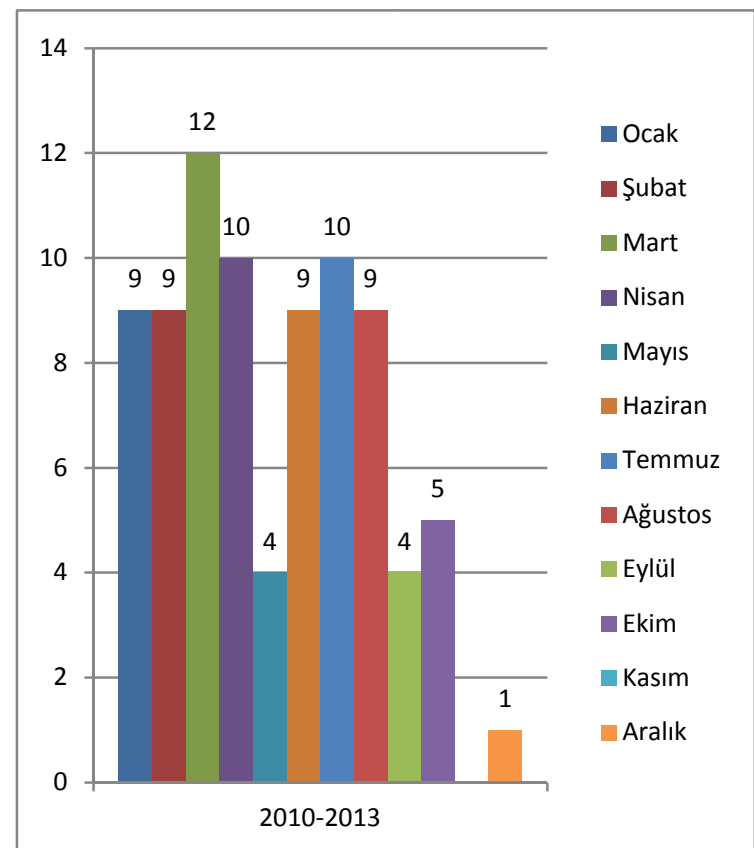

Grafik 7. 2010- 2013 Hırsızlık Suçlarının Aylara Göre Oluş Zamanlarının Mukayesesi Kaynak: Kırıkkale Adliyesi Arşivi (2013) 
2010-2013 yılları arasında hırsızlık olaylarına karışan 51 şüpheliden 7(\%14)'si kadın, 44(\%86)'ü ise erkektir.

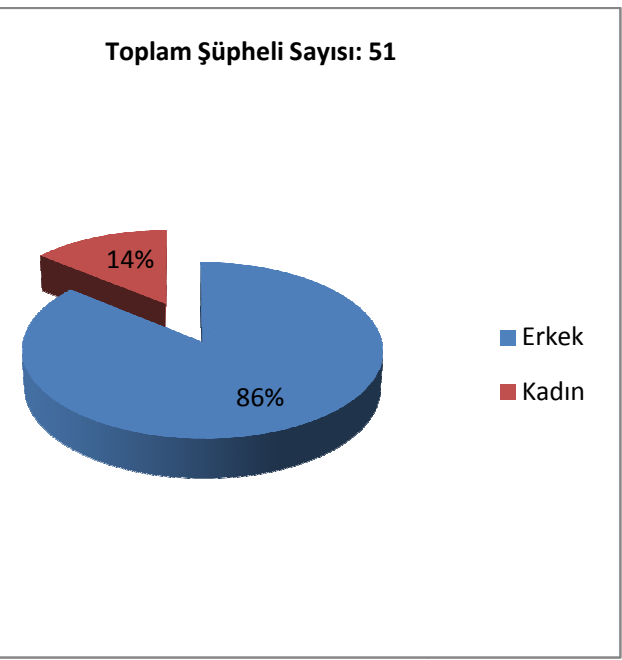

Grafik 8. 2010- 2013 Hırsızlık olaylarına karışan şüphelilerin cinsiyete göre dağılımları

Kaynak: Kırıkkale Adliyesi Arşivi (2013)

Kırıkkale ilinde meydana gelen malvarlığına karşı suçlar incelendiğinde özellikle yaz aylarında meydana gelen otodan hırsılık olayları göze çarpmaktadır. Gurbetçi vatandaşların da yol güzergâhını yoğun bir şekilde kullandığı yaz aylarında otodan hırsızlık olayları sıklıkla meydana gelmektedir. İstatistikler incelendiğinde bütün olayların Mayıs ve Ekim ayları arasında meydana geldiği görülmektedir.

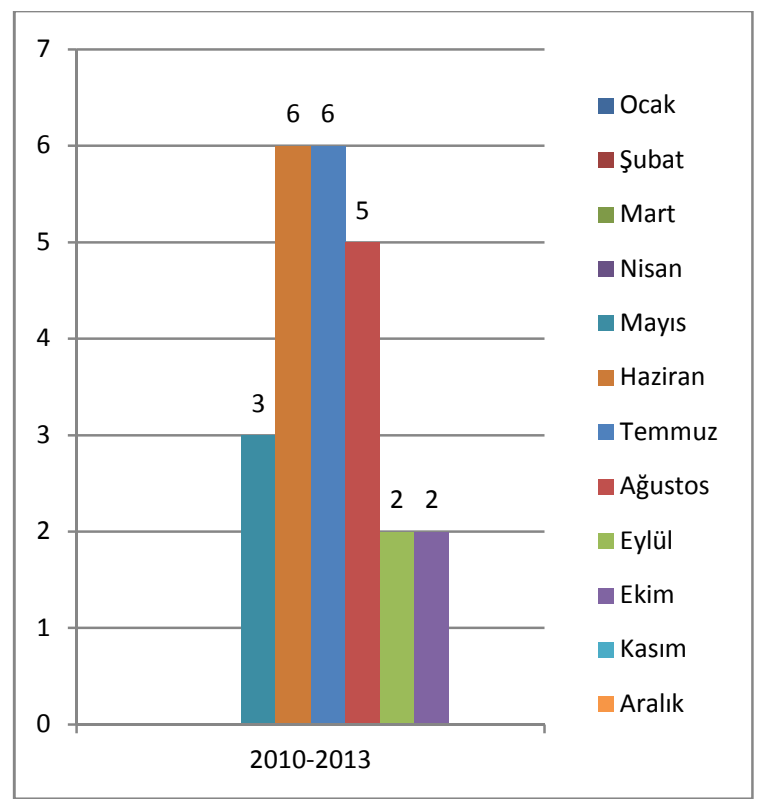

Grafik 9. 2010- 2013 Otodan Hırsızlık Olaylarının Aylara Göre Dağılımı

Kaynak: Kırıkkale Adliyesi Arşivi (2013)

Samsun ve Kayseri karayolları üzerindeki benzin istasyonları ve dinlenme tesisleri, yine aynı yol güzergâhları üzerinde bulunan çeşme başları ve yolcuların dinlenmek için mola verdikleri gölgelik alanlar otodan hırsızlık olaylarının meydana geldiği yerlerdir.

2010-2013 yılları arasında toplam 24 otodan hırsızlık olayı ile ilgili dava açılmıştır. Açılan davalar sonucunda otodan hırsızlık olaylarının 17(\%71)'sinin failleri belirlenmiş, 7(\%29)'si ise faili meçhul kalmıştır.

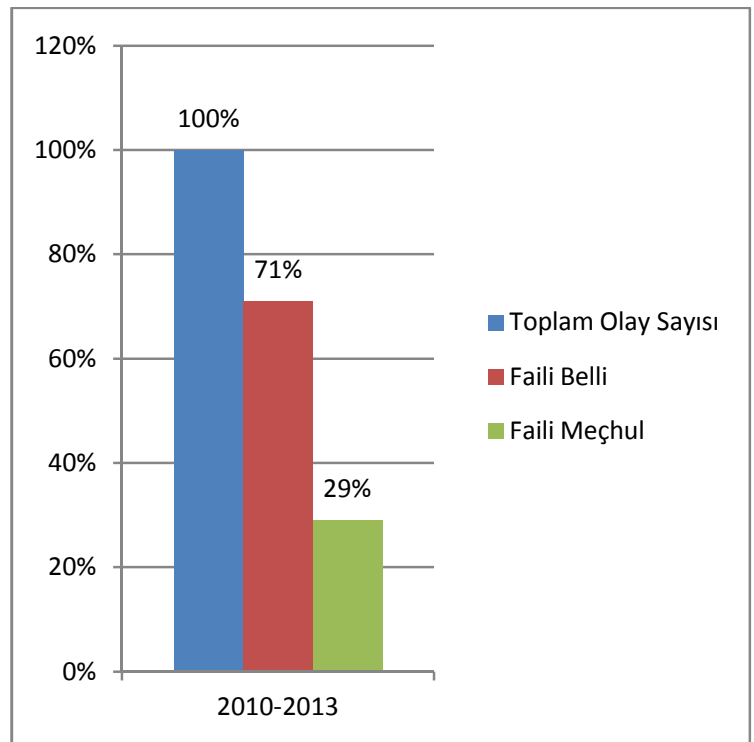

Grafik 10. 2010- 2013 Otodan Hırsızlık Olaylarının Faili Meçhul- Faili Belli Olay Mukayesesi

Kaynak: Kırıkkale Adliyesi Arşivi (2013)

Otodan hırsızlık olaylarına karşı alınabilecek tedbirler şunlardır:

$\checkmark$ Yol üzerinde bulunan dinlenme tesislerine ve benzin istasyonlarına kamera sistemi kurdurulmas1,

$\checkmark$ Benzin istasyonu ve dinlenme tesislerinin özel güvenlik tahsis etmesi,

$\checkmark$ Dinlenme tesislerinde otopark bölümlerinin ayrılması ve özel güvenlik görevlisi ile güvenliğinin sağlanması,

$\checkmark$ Otodan hırsızlık olaylarının yoğunlaştığı bölgelere MOBESE sisteminin kurulmas1,

$\checkmark$ Yol üzerinde bulunan gölgelik alanlara ve çeşme başlarına hırsızlık uyarı levhalarının konulması,

$\checkmark$ Kolluk tarafından olayların yoğunlaştığı bölgelere yaya ve motorlu devriyeler planlanmasi,

$\checkmark$ Anayol güzergâhlarında kolluk gücü tarafından önleyici faaliyet olarak durdurma ve kimlik sorma faaliyetlerinin icra edilmesi.

Kırıkkale ilinde evden hırsızlık ve işyerinden hırsızlık olayları göze çarpan diğer hırsızlık olaylarıdır. Evden hırsızlık olayları incelendiğinde yoğunluklu olarak bağ evinden hırsızlık olaylarının meydana geldiği görülmektedir. Söz konusu bağ evleri genellikle şehir merkezine uzak ve Kızılırmak kenarında bulunmaktadır. Bağ evleri kış aylarında boş kalmakta ve hırsızlık olaylarına maruz kalmaktadır. Evden hırsızlık olaylarına karşı olayların kış aylarında olduğu dikkate alınarak kolluk güçleri tarafından olayların oluş zamanları kontroller sıkılaştırılmalıdır.

Evden ve iş yerinden hırsızlık olaylarına karşı şu tedbirler alınmalıdır:

$\checkmark$ Özel kuruluşlarda ve kamu kuruluşlarında hırsızlık olaylarına karşı özel güvenlik görevlilerinin istihdam edilmesi,

$\checkmark$ Aydınlatma ihtiyacının olayların oluş yerlerine göre belirlenmesi ve sokakların aydınlatılması,

$\checkmark$ Evlerin kapılarının çelik kapı sistemleri ile değiştirilmesi,

$\checkmark$ Pencerelerin demir korkuluklar ile sağlamlaştırılması, 
Ev ve iş yeri giriş çıkışlarına kamera sistemleri kurulmasi,

$\checkmark$ Farklı bir yaklaşım olarak ev ve iş yeri giriş çıkışlarına kurulacak olan kamera sisteminin maliyeti sebebiyle sahte kameraların kurulması.

Hayvan hırsızlığı Kırıkkale ilinde sıklıkla görülen hırsızlık türlerinden birisi olarak karşımıza çıkmaktadır. Hayvan hırsızlığı büyükbaş ve küçükbaş hayvan hırsızlığı olarak ikiye ayrılmakta ve olayların oluş şekline göre iki tarzda gerçekleşmektedir. Birincisi olay yerinde hayvanların kesilerek hırsızlığa konu edilmesi, ikincisi ise hayvanların belli bir yükleme noktasına götürülerek sayıyla orantılı olarak pikap veya kamyon gibi araçlarla çalınmasıdır. Hayvan hırsılıkları yurt geneline benzer şekilde kurban bayramı öncesi Kırıkkale ilinde de yoğunlaşmaktadır. alınmalıdır:

Hayvan hırsızlığının önlenmesi için şu tedbirler

$\checkmark$ Kolluk güçleri tarafından sorumluluk bölgelerindeki ağıl ve hayvan sayılarının sıkı bir şekilde takip edilmesi,

$\checkmark$ Hayvan sahipleri ile toplum destekli güvenlik hizmeti kapsamında toplantılar düzenlenip, hırsızlık olaylarına karşı alınabilecek tedbirler konusunda bilgilendirilmesi,

$\checkmark$ Ağılların kapılarına kilit sistemi yapılması,

$\checkmark$ Ağılların kapılarına alarm sistemi kurulması,

$\checkmark$ Kolluk tarafindan çobanların kimlik sorgulamalarının yapılarak daha önce herhangi bir suça karışıp karışmadıklarının tespit edilmesi,

$\checkmark$ Ağılların giriş ve çıkışlarının 1şıklandırılması,

$\checkmark$ Mezbahaların sık sik denetlenmesi,

$\checkmark$ Hayvan pazarlarının denetimine sıkı bir şekilde devam edilmesidir.

\subsubsection{Topluma Karşı Suçlar ve Çözüm Önerileri}

2010-2013 yılları arasında meydana gelen toplam 28 topluma karşı suçun \%100’ü kamu güvenliğine karşı meydana gelmiş suçlardır. Kamu güvenine karşı suçları mühür bozma, resmi belgede sahtecilik, özel belgede sahtecilik gibi suçlar oluşturmaktadır.

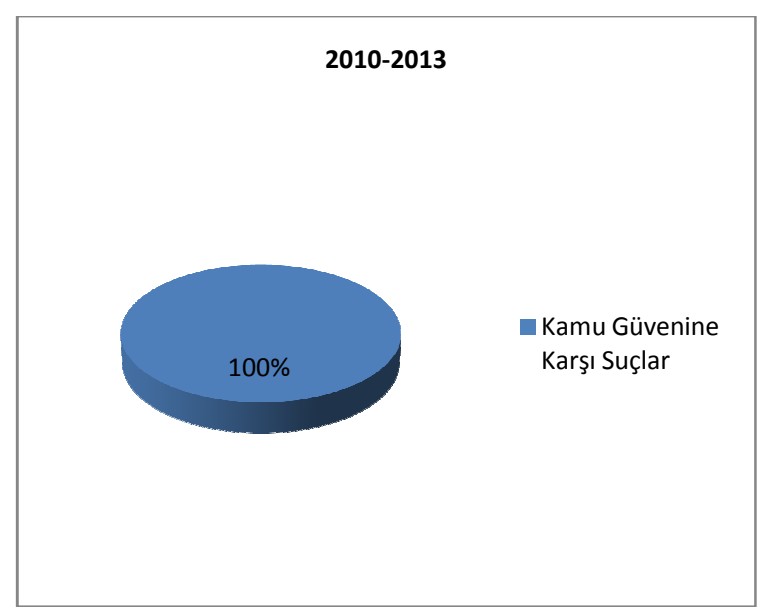

Grafik 11. 2010- 2013 Topluma Karşı Suçların Mukayesesi Kaynak: Kırıkkale Adliyesi Arşivi (2013)

Mühür bozma, resmi ve özel belgede sahtecilik gibi suçlarla mücadelede ilgili kolluk birimlerinin teknik ve bilgi kapasiteleri artırılmalıdır. İstihbarata dayalı çalışmaların yanında sık sık kontroller yapılmalıdır.
Kırıkkale ilinde özellikle sahte araç muayene pulu kullanma olayı meydana gelmektedir. Trafik ekipleri tarafından yapılan kontroller TÜVTÜRK ekipleri ile koordine edilmelidir.

\subsubsection{Millete ve Devlete Karşı Suçlar ve Çözüm} Önerileri

2010-2013 yılları arasında meydana gelen toplam 65 millete ve devlete karşı suçun \%100'ü 6136 sayılı Ateşli Silahlar ve Bıçaklar ile Diğer Aletler Hakkındaki Kanuna muhalefet şeklinde gerçekleşmiştir.

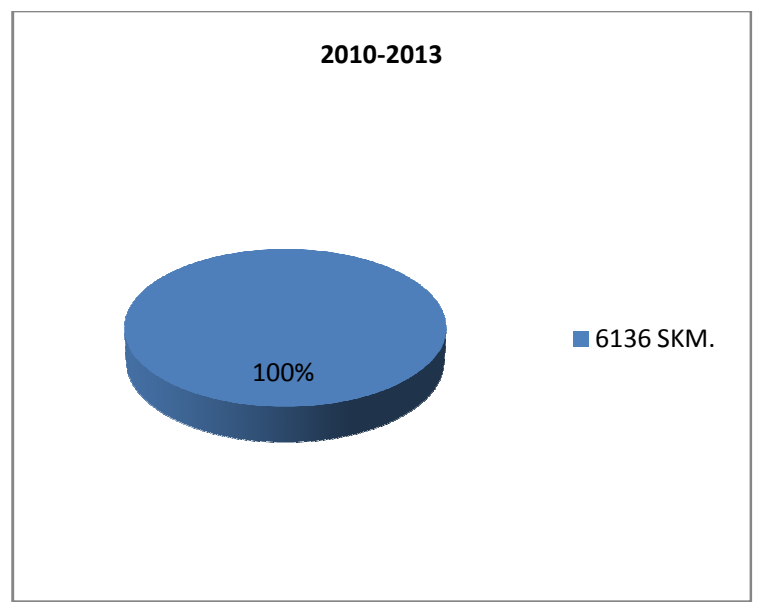

Grafik 12. 2010- 2013 Millete ve Devlete Karşı Suçların Mukayesesi

Kaynak: Kırıkkale Adliyesi Arşivi (2013)

Kırıkkale ilinde düğünlerde silah atma olayları yaygındır. Bunun yanında ruhsatsız silah ve kurusıkı silah taşıma olayları da sıklıkla görülmektedir. Düğünlerde silah atma olaylarına karşı özellikle köy düğünleri vatandaşı rahatsız etmeden takip edilmeli, devriyeler ile kontroller yapılmalıdır. Ruhsatsız silah bulundurma olaylarına karşı kolluk birimleri tarafından istihbari çalışmalar yapılmalı ve adli birimler vasıtası ile kesin şüphe oluştuğunda arama faaliyetleri yapilmalidir.

\subsubsection{Kaçakçılık Suçları ve Çözüm Önerileri}

2010-2013 yılları arasında meydana gelen toplam 65 kaçakçılık suçunun 59(\%90,76)'u 4733 sayılı Tütün ve Alkol Piyasası Düzenleme Kurumu Teşkilat ve Görevleri Hakkındaki Kanuna muhalefet, 6(\%9,24)'sı kullanmak için uyuşturucu madde bulundurmak ve satmak şeklinde gerçekleşmiştir. 


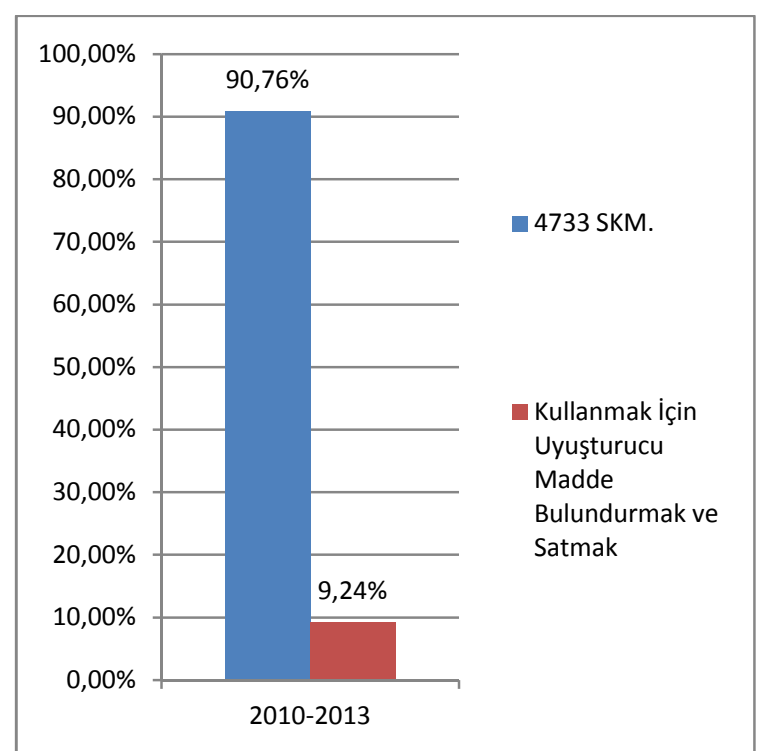

Grafik 13. 2010- 2013 Kaçakçılık Suçlarının Mukayesesi Kaynak: Kırıkkale Adliyesi Arşivi (2013)

Kırıkkale ili kaçakçılık suçlarının yoğun olarak gerçekleştiği bölgelerden birisi olarak karşımıza çıkmaktadır. Kaçakçılık suçları Kırıkkale ilinde iki şekilde kendisini göstermektedir. İlk olarak akaryakıt kaçakçılığı belirgin olarak ortaya çıkmaktadır. Kaçak akaryakıtın yanında TÜPRAŞ Rafinerisinden çeşitli hileli yollarla alınan fazla akaryakıtın satışı da dikkati çekmektedir. Rafineri girişinde tankerler boş olarak tartılmakta, çıkışta ise dolu olarak tartılıp aldıkları akaryakıt miktarı ölçülmektedir. Boş olarak tartılma esnasında araca ağırlık konarak ağırlığı fazla gösterilmekte ve fazla alınan akaryakıt tanker şoförleri tarafından ucuz fiyata satılmaktadır. Diğer bir kaçakçılık olayı olarak sigara kaçakçılığ 1 karşımıza çıkmaktadır. Doğudan gelen tren ve araçlarla Kırıkkale ilinden çok sayıda kaçak sigara geçmektedir. Her iki kaçakçılık olayı için kolluk güçleri tarafından istihbarata dayalı çalışmalar yapılmalı ve kontroller sıkılaştırılmalıdır.

Kullanmak için uyuşturucu bulundurmak ve satmak suçu çok yoğun olmamakla birlikte Kırıkkale ilinde meydana gelen suçlar arasındadır. Genellikle sahipsiz arazilere ekilen kenevir ve küçük miktarlarda yakalanan uyuşturucu maddeler göze çarpmaktadır. Güvenlik güçleri tarafından hâlihazırda yapılmakta olan çalışmalar yeterli seviyededir. Ek olarak konu ile ilgili ailelerin ve gençlerin bilgilendirilmesi ve uyarılması maksadıyla yapılacak olan toplum destekli güvenlik uygulamalarının katkısı olacaktır.

\subsubsection{Meydana Gelen ve Faili Meçhul Kalan Olay Miktarı}

2010- 2013 yılları arasında meydana gelen toplam 417 olaydan 353'ü aydınlatılmış, 64 olay faili meçhul kalmış olup, aydınlatma oranı \% 85'dir. Faili meçhul kalan olaylar incelendiğinde kolluk güçleri tarafından yapılan hatalar göze çarpmaktadır. Tecrübesiz personel tarafından delillerin eksik toplanması veya olay yerinin ayrıntılı incelenmemesi sonucu delillerin kaybolduğu görülmektedir. Bu noktada kolluk güçlerinin olay yeri inceleme konusunda sahip olduğu yeterlilik seviyesinin olayın çözümü ile doğrudan ilişkili olduğu görülmektedir. Unutulmamalıdır ki her olayda bir iz mutlaka vardır. Ve yine unutulmamalıdır ki ilk anda toplanmayan her delil ya zaman içinde kaybolacaktır ya da değişime uğrayacaktır.

\section{Sonuç}

Suçla mücadele suç öncesi ve suç sonrası olarak ikiye ayrılmaktadır. Suç sonrası, suçlunun yakalanması, cezalandırılması ve ıslah edilmesini kapsamaktadır. Suç öncesi ise suçun meydana gelmesini önleyen, hem kişiler hem kurumlar hem de güvenlikten sorumlu polis ve jandarmanın caydırıcı tedbirler aldığı aşamadır. Suçun işlenmesi sadece polisiye tedbirler alınarak önlenememektedir. Suçun hedefi olan eşya veya kimseyi uygun bir hedef konumundan çıkarmak suçun oluşumunu önlemede etkili bir yöntemdir.

Proaktif yaklaşımla alınabilecek basit güvenlik tedbirleri caydırıcı olabilmekte, suçu daha işlenmeden engelleyebilmektedir. Bahse konu tedbirlerin bazıları maliyet gerektirdiği gibi maliyeti neredeyse hiç olmayan basit tedbirlerde vardır. Örneğin: Hurdacılardan çok düşük bedelle alınıp kapı girişlerine takılabilecek çalışmayan kameralar caydırıcı olacaktır. Ağıl girişlerine takılacak mıknatıslı alarmlar veya ağıl girişlerinin aydınlatılması hırsızlık olaylarını engelleyecektir. Örnekler insan zekâsı ile sınırlı olup bir sınırı yoktur. Polis ve jandarmanın suç önlemedeki yeri ve görevleri tartışılmazdır. Ancak suçla mücadele alınacak polisiye tedbirlerin yanında kişi veya kurumlarca suça zemin hazırlayan, suçun işlenmesini kolaylaştıran faktörlerin ortadan kaldırılmasıyla etkin olacaktır.

Özelde Kırıkkale ili değerlendirildiğinde ilk olarak emniyet güçleri tarafından kurulacak olan bir komisyonun marifetiyle 1şıklandırma sorunu olan bölgeler tespit edilmeli ve gerekli kurumlarla koordine kurularak problem çözülmelidir. Bir kısmı şehir merkezinde bulunan ve konum itibariyle çarşı içerisinde yer alan bar, pavyon ve içkili mekânlar için şehir dışında ayrı bir bölge tahsis edilmeli ve kolluk güçlerinin yanında özel güvenlik görevlileri ve kamera sistemleriyle bu bölgenin güvenliği sağlanmalıdır. Şehir içerisinde bulunan metruk binalar sorunu kapsamlı bir proje ile çözüme kavuşturulmalıdır. Kamu kurumları ve özel kurumlar özel güvenlik hizmeti almaları konusunda teşvik edilmelidir. İlgili kurumlarla ortak yapılacak bir çalışmayla şehirde yaşayan uyuşturucu bağımlısı, tinerci ve balici kimselerin tedavi edilmesi ve topluma kazandırılması sağlanmalıdır. Hâlihazırda uygulanmakta olan toplum destekli güvenlik uygulaması daha kapsamlı bir şekilde uygulanmaya devam edilmelidir. Güvenlik güçleri tarafından oluşturulacak bir komisyonla Kayseri ve Samsun karayolları üzerinde bulunan hırsızlığa müsait noktalar tespit edilmeli ve bu noktalar 1şıklandırma ve güvenlik kameraları ile güvenli hale getirilmelidir.

\section{Kaynakça}

Dolu, Osman (2012), Suç Teorileri, Seçkin Yayınları, Ankara.

Dolu, Osman (2009 a), “Caydırıcılığın Sınırları: Caydırıcılık Eksenli Suç Önleme ve Mücadele Politikalarına Eleştirisel Bir Yaklaşım”, Polis Bilimleri Dergisi Cilt: 11 (3).

Dolu, Osman (2009 b), "Bir Firsat Olarak Suç: Suçun Durumsal Belirleyicileri, Suç Fırsatları ve Rutin Faaliyetler Teorisi”, Polis Bilimleri Dergisi Cilt:11 (2). 
Doğan, Halil İbrahim (2011), "Suç Teorileri ve Şehir Güvenliği: Bitlis İliyle İlgili Genel Bir Değerlendirme”, Polis Bilimleri Dergisi Cilt: 13 (4).

Geleri, Aytekin (2010), "Şehirlerde Suç Önleme Politikalarının Geliştirilmesi", Polis Bilimleri Dergisi Cilt:12 (3).

T.C. İçişleri Bakanlığı Araştırma ve Etütler Merkezi (2003), "Bir Toplum Destekli Polislik Hizmeti Modeli, Suçla Mücadele Stratejisi Araştırma Projesi”, Ankara.

Ulusal Yargı Ağı Bilişim Sistemi (2013), http://www.uyap.gov.tr/tanitim/tarihce.html, (erişim tarihi 04.06.2013).

Türkiye İstatistik Kurumu (2013), http://tuikapp.tuik.gov.tr/adnksdagitapp//adnks.zul, （erişim tarihi 04.06.2013).

Kırıkkale Adliyesi Arşivi (2013). 